\title{
Overall Equipment Effectiveness as a Maintenance Management Analysis Tool for a Crumb Rubber Production Line.
}

\author{
Godlove Nfor Njeshu' ${ }^{1}$, Willibroad Abongwa Acho², Nde Divine Bup ${ }^{3}$ \\ ${ }^{1}$ Department of Mechanical Engineering, Modibbo Adama University of Technology Yola, Nigeria \\ goddynjeshu@gmail.com \\ ${ }^{2}$ Department of Mechanical Engineering, COT-University of Buea, Cameroon \\ ${ }^{3}$ Department of Food and Bio-Resource Technology, COLTECH-University of Bamenda, Cameroon.
}

\begin{abstract}
Overall Equipment Effectiveness (OEE) calculations were carried out on a field crumb production line in order to determine its amelioration potentials and evaluate the maintenance policy of the factory. The OEE of individual machines making up the field crumb line as well as that of the entire line has been calculated using data collected over a one month period. The OEE values obtained ranged from as low as $24.1 \%$ for the pre-breaker to just over $60 \%$ for crepper 4 and increases with increase in any of the three production parameters - machine availability, performance efficiency, or rate of quality product. These results show that the line possesses enormous amelioration potentials. The factory productivity is found to be greatly enhanced by even slight improvements of the OEE value. Skeletal improvement strategies implemented, turned out very encouraging results - a $14 \%$ rise in the OEE value of the pre-breaker was obtained. Other machines on the line showed a similar improvement. The production line OEE has witnessed an increase from $43.7 \%$ to $49.9 \%$ corresponding to an increase in productivity of 0.42 tons per hour. Plant productivity can therefore be boosted by use of OEE as a maintenance management analysis tool.
\end{abstract}

Keywords-Overall Equipment Effectiveness, machine availability, performance efficiency, rate of quality product, productivity.

\section{INTRODUCTION AND REVIEW}

In today's fast growing economies in Sub Saharan Africa, engineers are realizing the need to justify expenditure on plant and the equipment therein. Once a plant has been set up, it is essential that it operates effectively and remains profitable to the investors.

The processing of field crumb (FC) rubber begins with the cleaning of the rubber coagulum from the field in the intake pit. The slab cutter (SC) then cuts the coagulum into smaller sizes that can be managed by the pre-breaker (PB). The PB breaks the coagulum into small pieces before the first series of four creppers (CR) act on the crop. After this it is shredded by shredder (SH 1) before the last series of creping by three creppers. It is again shredded upon and finally conveyed into the dryer through a vibrating screen assisted by transfer pumps. From the dryer the FC rubber is moulded into bales of $35 \mathrm{~kg}$ each and packed into crates for exportation.

At the Central Rubber Factory Tiko; which is the major cup lumb processing unit for Cameroon Development Corporation, (CDC); cup lumbs from the farm remain unprocessed for longer than expected due principally to very low machine output. From statistics available at the factory over a fourteen months' period, the factory fell short of its production targets by an average value of about 228 tons of field crumb rubber monthly [1]. These losses represent about 125 million FCFA (about 62.5 million dollars) for the company and could be due to; inadequate manpower allocation, insufficient supply of spares for the production line, absence of the culture of periodic machine overhaul, limited adequately trained technicians to attend to the machines leading to low machine output. All these led to the accumulation of cup lumbs which apart from the negative economic impact on the company poses a serious environmental problem.

The machine productivity (i.e. tons of output per machine-hour), for the Field Crumb (FC) processing line from April to June of 2004 stands at 0.66 tons per hour; and corresponding labour productivity is equally low. In addition to low machine output, the factory's laboratory report between January and June 2004 showed a drastic drop in the quality of processed rubber on this line. For example in January 2004, 100\% of the CNR 10 grade processed met up with the quality specifications whereas, only $93.6 \%$ of the same grade was certified the next month and in April of the same year it dropped further to 91.5\% [2].

Both the low productivity and quality standards cited above cannot be isolated from the low machine availability. The FC line is suppose to run for twenty-four (24) hours daily; but it is usual to have a machine on the line with a downtime of three to four days (see machine downtime data collected). Even when the machines are available, their performance efficiency is considerably low. The fastest machine on the line is crepper 1 with an actual cycle time of 0.2 hours, which is far above its expected value of 0.16 hours as per machine manual. 
The factory is in a dire need of a well defined maintenance policy to carter for these problems. This research work therefore focused on developing a maintenance management analysis tool that will act as a mirror to the maintenance department and consequently ignite improvement strategies on the overall performance of the factory. The following specific objectives were defined: to calculate the OEE for each machine and subsequently that for the entire production line in order to be able to propose methods of ameliorating their performance; encourage the institutionalization of the use of OEE for maintenance management analysis and benchmarking.

\section{A. The Choice of Overall Equipment Effectiveness (OEE) for this Factory}

The choice of a particular analysis tool is strictly a function of the factory in question. In this research OEE was chosen for the following reasons: its simplicity and ability to promote the most needed synergy among workers. OEE is comparatively cheap to implement since the data required was to be manually collected. It has the advantage of being the single analysis tool that takes into consideration all three major production improvement parameters - quality rate, performance efficiency, and machine availability (i.e. time, speed and quality of equipment operation). OEE is thus preferred for this factory since it will provide an integral solution to the problems of quality, performance efficiency and availability encountered by the factory. Wherever OEE has been implemented, dramatic successes have been the outcome, like in Japan where it catapulted Japanese products in the world market at the expense of the Americans. Japan's productivity improved a dramatic 68\% between 1977 and1986, far outpacing the 26\% U.S increase over the same period. [3]. This is the period when TPM was most popular in Japanese factories. So why not give CDC the chance to experience such marvelous results.

\section{B. OEE Calculations}

The OEE index could be calculated for single machines or for an entire plant. For a series of machines with different capacities, if the series is "balanced" (i.e. the nameplate capacity of all contributing machines is designed to produce at reasonably close to the same rate), the speed of the fastest machine is taken as the ideal cycle time for all the machines in the series or production line [4]. This forces the maintenance department to recognize all other bottlenecks and strive to improve them. In cases where a series is not balanced, if any of the machines has a nameplate capacity that far exceeds the others, i.e. if there exist an "accumulator" or a "buffer", or a piece of equipment that was introduced to the line as an after-thought, such should be neglected [5], [6]

For entire plants, a straight average or weighted average method can be used. In the straight average method, a straight average is calculated for each OEE factor by summing the percentages for that factor across all processes, and dividing the results by the number of processes. Plant OEE is then obtained as always by multiplying the three OEE factors; as illustrated in equation (1). A weighted average is a more sophisticated approach that independently weighs each process by the planned production time for the same process and sums these results. This number is then divided by the sum of all the planned production times. [4].

$$
\text { OEE }=\text { OTR } \times \text { OPR } \times \text { QR }
$$

Where;

OEE is the Overall Equipment Effectiveness

OTR is defined as Operation Time Ratio

OPR is the Operation Performance Ratio and QR is the Quality Rate

While reference [7] fixes the OEE index of any sound production unit at $85 \%+$, reference [8] prefers to leave $85 \%+$ to world class manufacturing firms and recommends any value above $45 \%$ as acceptable for average industries worldwide.

\section{MATERIALS AND METHOD.}

\section{A. Materials}

The materials used included essentially measuring instruments such as a stop watch, vernier caliper, meter rule or tape; and a beam balance.

\section{B. Method}

An OEE diagnostic study was carried out to assess both machine performance and work methods in each work station, and data regarding machine performance was collected along the FC production line. Each machine time was broken down into the "six big machine losses"; equipment failure, setup and adjustment, idling and minor stoppages, reduced speed, process defects and reduced yields (tables I and II); and their respective OEE values calculated "as it is". Goals and targets [7] were then set up for the amelioration of the OEE index for the pre-breaker in particular, (the worst performing machine), and the FC line in general, within a well defined time frame and a factory performance improvement strategy was then put in place. After the implementation of these strategies, data was again collected and a new OEE index calculated for the FC line. This process is iterative until the desired OEE index for the factory is attained. 


\section{RESULTS AND DISCUSSION}

Tables I and II present the breakdown of each machine time into the six big losses.

The calculations for OEE per machine and for the entire FC line for the month of June; "as it is"; is presented in table III while table IV shows the same calculations for the month of August after OEE amelioration strategies had been effected on the production line.

TABLE I Breakdown of Total Machine Losses for June into the Six Losses.

\begin{tabular}{|c|c|c|c|c|c|}
\hline Machine & Failures & Adjustment/Setup & Idling/Minor stoppages & Reduced Speed & Defects in process \\
\hline SC & 70.8 & 65.0 & 48.3 & 111.1 & 0.90 \\
\hline PB & 40.3 & 74.8 & 56.4 & 157.2 & 0.81 \\
\hline CR1 & 56.4 & 72.5 & 93.3 & 91.8 & 0.91 \\
\hline CR2 & 172.1 & 7.5 & 81.2 & 47.8 & 0.62 \\
\hline CR3 & 0.0 & 0.0 & 105.9 & 87.5 & 1.0 \\
\hline CR4 & 0.0 & 0.0 & 102.5 & 67.4 & 0.99 \\
\hline CR5 & 39.7 & 42.1 & 77.2 & 53.5 & 0.97 \\
\hline CR6 & 29.9 & 49.5 & 82.3 & 62.2 & 0.96 \\
\hline CR7 & 27.6 & 59.3 & 70.3 & 58.7 & 0.97 \\
\hline SH1 & 64.5 & 82.3 & 69.1 & 64.5 & 0.81 \\
\hline SH2 & 55.3 & 79.5 & 73.1 & 62.2 & 0.84 \\
\hline
\end{tabular}

TABLE II Breakdown of Total Machine Losses for August into the Six Losses.

\begin{tabular}{|c|c|c|c|c|c|}
\hline Machine & Failures & Adjustment/Setup & Idling/Minor stoppages & Reduced Speed & Defects in process \\
\hline SC & 56.0 & 55.1 & 8.3 & 18.9 & 0.14 \\
\hline PB & 25.0 & 51.5 & 9.2 & 21.2 & 0.14 \\
\hline CR1 & & & 15.9 & 15.3 & 0.15 \\
\hline CR2 & 47.7 & 26.4 & 13.9 & 8.1 & 0.12 \\
\hline CR3 & 10.6 & 0.0 & 16.8 & 14.3 & 0.13 \\
\hline CR4 & 0.0 & 0.0 & 17.6 & 11.7 & 0.15 \\
\hline CR5 & 29.2 & 32.9 & 13.4 & 9.1 & 0.13 \\
\hline CR6 & 24.1 & 38.9 & 12.1 & 10.6 & 0.12 \\
\hline CR7 & 22.2 & 48.6 & 11.8 & 10.2 & 0.14 \\
\hline SH1 & 50.9 & 69.0 & 11.8 & 11.4 & 0.16 \\
\hline SH2 & 43.1 & 61.1 & 12.9 & 10.8 & 0.15 \\
\hline
\end{tabular}

TABLE III OEE Calculation Sheet for June

\begin{tabular}{|c|c|c|c|c|c|c|c|c|c|c|c|c|c|c|c|}
\hline & $\begin{array}{l}\text { PPT } \\
\text { (hr) }\end{array}$ & $\begin{array}{l}\text { DTL } \\
\text { (hr) }\end{array}$ & $\begin{array}{l}\text { MS } \\
\text { (hr) }\end{array}$ & $\begin{array}{l}\text { OT } \\
\text { (hr) }\end{array}$ & $\begin{array}{l}\text { APT } \\
(h r)\end{array}$ & $\begin{array}{l}\text { OT } \\
\text { R } \\
\text { (\%) }\end{array}$ & $\begin{array}{l}\text { NO } \\
\text { R } \\
\text { (\%) }\end{array}$ & $\begin{array}{l}\text { Plus } \\
\text { losse } \\
\text { s } \\
\text { (tons } \\
\text { ) }\end{array}$ & $\begin{array}{l}\text { Qty } \\
\text { Prd } \\
\text { (tons } \\
\text { ) }\end{array}$ & $\begin{array}{l}\text { TC } \\
\mathrm{T} \\
(\mathrm{hr} \\
)\end{array}$ & $\begin{array}{l}\text { AC } \\
\text { T } \\
\text { (hr) }\end{array}$ & $\begin{array}{l}\text { QR } \\
\text { (\%) }\end{array}$ & $\begin{array}{l}\text { OS } \\
\mathrm{R} \\
(\%)\end{array}$ & $\begin{array}{l}\text { OP } \\
\mathrm{R} \\
(\%)\end{array}$ & $\begin{array}{l}\text { OE } \\
\mathrm{E} \\
\text { (\%) }\end{array}$ \\
\hline SC & $\begin{array}{r}575 . \\
7 \\
\end{array}$ & $\begin{array}{r}135 . \\
8 \\
\end{array}$ & 48.3 & $\begin{array}{r}439 . \\
9\end{array}$ & $\begin{array}{r}391 . \\
6\end{array}$ & 76.4 & 89.0 & $\begin{array}{r}380 . \\
8 \\
\end{array}$ & $\begin{array}{r}375 . \\
1 \\
\end{array}$ & 0.2 & $\begin{array}{r}0.2 \\
2 \\
\end{array}$ & 98.5 & 72.7 & 64.7 & 48.7 \\
\hline PB & $\begin{array}{r}575 . \\
7 \\
\end{array}$ & $\begin{array}{r}115 . \\
1 \\
\end{array}$ & $\begin{array}{r}108 . \\
1 \\
\end{array}$ & $\begin{array}{r}460 . \\
6 \\
\end{array}$ & $\begin{array}{r}352 . \\
5 \\
\end{array}$ & 80.0 & 76.5 & $\begin{array}{r}380 . \\
8 \\
\end{array}$ & $\begin{array}{r}375 . \\
1 \\
\end{array}$ & 0.2 & $\begin{array}{r}0.4 \\
0 \\
\end{array}$ & 98.5 & 40.0 & 30.6 & 24.1 \\
\hline CR1 & $\begin{array}{r}575 . \\
7 \\
\end{array}$ & $\begin{array}{r}128 . \\
9 \\
\end{array}$ & $\begin{array}{r}110 . \\
6 \\
\end{array}$ & $\begin{array}{r}446 . \\
8 \\
\end{array}$ & $\begin{array}{r}336 . \\
2 \\
\end{array}$ & 77.6 & 75.2 & $\begin{array}{r}380 . \\
8 \\
\end{array}$ & $\begin{array}{r}375 . \\
1 \\
\end{array}$ & 0.2 & $\begin{array}{r}0.2 \\
5 \\
\end{array}$ & 98.5 & 64.0 & 48.1 & 36.8 \\
\hline CR 2 & $\begin{array}{r}575 . \\
7 \\
\end{array}$ & $\begin{array}{r}179 . \\
6 \\
\end{array}$ & $\begin{array}{r}107 . \\
6 \\
\end{array}$ & $\begin{array}{r}396 . \\
1 \\
\end{array}$ & $\begin{array}{r}288 . \\
5 \\
\end{array}$ & 68.8 & 72.8 & $\begin{array}{r}380 . \\
8 \\
\end{array}$ & $\begin{array}{r}375 . \\
1 \\
\end{array}$ & 0.2 & $\begin{array}{r}0.2 \\
3 \\
\end{array}$ & 98.5 & 69.6 & 50.7 & 34.3 \\
\hline CR3 & $\begin{array}{r}575 . \\
7 \\
\end{array}$ & 0.0 & $\begin{array}{r}106 . \\
1 \\
\end{array}$ & $\begin{array}{r}575 . \\
7 \\
\end{array}$ & $\begin{array}{r}469 . \\
6 \\
\end{array}$ & 100 & 81.5 & $\begin{array}{r}380 . \\
8 \\
\end{array}$ & $\begin{array}{r}375 . \\
1 \\
\end{array}$ & 0.2 & $\begin{array}{r}0.2 \\
3 \\
\end{array}$ & 98.5 & 69.6 & 56.7 & 55.9 \\
\hline CR4 & $\begin{array}{r}575 . \\
7 \\
\end{array}$ & 0.0 & $\begin{array}{r}109 . \\
8 \\
\end{array}$ & $\begin{array}{r}575 . \\
7 \\
\end{array}$ & $\begin{array}{r}465 . \\
9 \\
\end{array}$ & 100 & 80.9 & $\begin{array}{r}380 . \\
8 \\
\end{array}$ & $\begin{array}{r}375 . \\
1 \\
\end{array}$ & 0.2 & $\begin{array}{r}0.2 \\
1 \\
\end{array}$ & 98.5 & 76.2 & 61.7 & 60.7 \\
\hline CR5 & 575. & 81.8 & 109. & 493. & 384. & 85.7 & 77.9 & 380. & 375. & 0.2 & 0.2 & 98.5 & 72.7 & 56.7 & 47.9 \\
\hline
\end{tabular}




\begin{tabular}{|l|r|r|r|r|r|r|r|r|r|r|r|r|r|r|r|}
\hline & 7 & & 1 & 9 & 8 & & & 8 & 1 & & 2 & & & & \\
\hline CR6 & 575. & 79.4 & 109. & 496. & 386. & 86.2 & 77.9 & 380. & 375. & 0.2 & 0.2 & 98.5 & 80.0 & 62.3 & 52.9 \\
& 7 & & 7 & 3 & 6 & & & 8 & 1 & & 0 & & & & \\
\hline CR7 & 575. & 86.9 & 107. & 488. & 381. & 84.9 & 78.0 & 380. & 375. & 0.2 & 0.2 & 98.5 & 76.2 & 59.5 & 49.7 \\
& 7 & & 3 & 8 & 5 & & & 8 & 1 & & 1 & & & & \\
\hline SH1 & 575. & 146. & 114. & 428. & 314. & 74.5 & 73.3 & 380. & $\begin{aligned} 375 . \\
0.2\end{aligned}$ & 0.2 & 0.2 & 98.5 & 69.6 & 51.0 & 37.4 \\
& 7 & 8 & 3 & 9 & 6 & & & 8 & 1 & & 3 & & & & \\
\hline SH2 & 575. & 134. & 105. & 440. & 335. & 76.6 & 76.1 & 380. & $\begin{aligned} 375 . \\
.\end{aligned}$ & 0.2 & 0.2 & 98.5 & 66.7 & 50.7 & 38.3 \\
& 7 & 8 & 2 & 9 & 7 & & & 8 & 1 & & 4 & & & & \\
\hline
\end{tabular}

TABLE IV OEE Calculation Sheet for August

\begin{tabular}{|c|c|c|c|c|c|c|c|c|c|c|c|c|c|c|c|}
\hline & $\begin{array}{l}\text { PPT } \\
\text { (hr) }\end{array}$ & $\begin{array}{l}\text { DTL } \\
\text { (hr) }\end{array}$ & $\begin{array}{l}\text { MS } \\
\text { (hr) }\end{array}$ & $\begin{array}{l}\text { OT } \\
\text { (hr) }\end{array}$ & $\begin{array}{l}\text { APT } \\
\text { (hr) }\end{array}$ & $\begin{array}{l}\text { OT } \\
\text { R } \\
\text { (\%) }\end{array}$ & $\begin{array}{l}\text { NO } \\
\text { R } \\
(\%)\end{array}$ & $\begin{array}{l}\text { Plus } \\
\text { losse } \\
\text { s } \\
\text { (tons } \\
\text { ) }\end{array}$ & $\begin{array}{l}\text { Qty } \\
\text { Prd } \\
\text { (tons } \\
\text { ) }\end{array}$ & $\begin{array}{l}\text { TC } \\
\text { T } \\
\text { (hr) }\end{array}$ & $\begin{array}{l}\text { AC } \\
\text { T } \\
\text { (hr) }\end{array}$ & $\begin{array}{l}\text { QR } \\
\text { (\%) }\end{array}$ & $\begin{array}{l}\text { OS } \\
\mathrm{R} \\
(\%)\end{array}$ & $\begin{array}{l}\mathrm{OP} \\
\mathrm{R} \\
(\%)\end{array}$ & $\begin{array}{l}\text { OE } \\
\mathrm{E} \\
\text { (\%) }\end{array}$ \\
\hline SC & 463 & $\begin{array}{r}111 . \\
1\end{array}$ & $\begin{array}{r}38 . \\
4\end{array}$ & $\begin{array}{r}351 . \\
9\end{array}$ & 13.5 & 76.0 & 89.1 & 505.3 & 01.2 & 0.2 & $\begin{array}{r}0.2 \\
1\end{array}$ & $\begin{array}{r}99 . \\
2\end{array}$ & $\begin{array}{r}76 . \\
2\end{array}$ & 67.9 & 51.2 \\
\hline PB & 463 & 76.5 & $\begin{array}{r}42 . \\
6\end{array}$ & $\begin{array}{r}386 . \\
5\end{array}$ & 43.9 & 83.5 & 88.9 & 505.3 & 01.2 & 0.2 & $\begin{array}{r}0.3 \\
1\end{array}$ & $\begin{array}{r}99 . \\
2\end{array}$ & $\begin{array}{r}51 . \\
6\end{array}$ & 45.9 & 38.0 \\
\hline CR1 & 463 & $\begin{array}{r}106 . \\
0\end{array}$ & $\begin{array}{r}73 . \\
6\end{array}$ & $\begin{array}{r}357 . \\
0\end{array}$ & 83.4 & 77.1 & 79.4 & 505.3 & 01.2 & 0.2 & $\begin{array}{r}0.2 \\
6\end{array}$ & $\begin{array}{r}99 . \\
2\end{array}$ & $\begin{array}{r}61 . \\
5\end{array}$ & 48.8 & 37.4 \\
\hline CR 2 & 463 & 74.1 & $\begin{array}{r}64 . \\
3 \\
\end{array}$ & $\begin{array}{r}388 . \\
9 \\
\end{array}$ & 324.6 & 84.0 & 83.5 & 505.3 & 501.2 & 0.2 & $\begin{array}{r}0.2 \\
4 \\
\end{array}$ & $\begin{array}{r}99 . \\
2 \\
\end{array}$ & $\begin{array}{r}66 . \\
7 \\
\end{array}$ & 55.6 & 46.4 \\
\hline CR3 & 463 & 10.6 & $\begin{array}{r}77 . \\
8 \\
\end{array}$ & $\begin{array}{r}452 . \\
4 \\
\end{array}$ & 374.6 & 97.7 & 82.8 & 505.3 & 501.2 & 0.2 & $\begin{array}{r}0.2 \\
3 \\
\end{array}$ & $\begin{array}{r}99 . \\
2 \\
\end{array}$ & $\begin{array}{r}69 . \\
6 \\
\end{array}$ & 57.6 & 55.8 \\
\hline CR4 & 463 & 0.0 & $\begin{array}{r}81 . \\
5 \\
\end{array}$ & $\begin{array}{r}463 . \\
0 \\
\end{array}$ & 381.5 & 100 & 82.4 & 505.3 & 501.2 & 0.2 & $\begin{array}{r}0.2 \\
1 \\
\end{array}$ & $\begin{array}{r}99 . \\
2 \\
\end{array}$ & $\begin{array}{r}76 . \\
2 \\
\end{array}$ & 62.8 & 62.3 \\
\hline CR5 & 463 & 62.0 & $\begin{array}{r}62 . \\
0 \\
\end{array}$ & $\begin{array}{r}401 . \\
0 \\
\end{array}$ & 339.0 & 86.6 & 84.5 & 505.3 & 501.2 & 0.2 & $\begin{array}{r}0.2 \\
2 \\
\end{array}$ & $\begin{array}{r}99 . \\
2 \\
\end{array}$ & $\begin{array}{r}72 . \\
7 \\
\end{array}$ & 61.5 & 52.8 \\
\hline CR6 & 463 & 63.0 & $\begin{array}{r}56 . \\
0 \\
\end{array}$ & $\begin{array}{r}400 . \\
0 \\
\end{array}$ & 44.0 & 86.4 & 86.0 & 505.3 & 501.2 & 0.2 & $\begin{array}{r}0.2 \\
0 \\
\end{array}$ & $\begin{array}{r}99 . \\
2 \\
\end{array}$ & $\begin{array}{r}80 . \\
0 \\
\end{array}$ & 68.6 & 58.9 \\
\hline CR7 & 463 & 70.8 & $\begin{array}{r}54 . \\
6 \\
\end{array}$ & $\begin{array}{r}392 . \\
2 \\
\end{array}$ & 337.6 & 84.7 & 86.1 & 505.3 & 501.2 & 0.2 & $\begin{array}{r}0.2 \\
1 \\
\end{array}$ & $\begin{array}{r}99 . \\
2 \\
\end{array}$ & $\begin{array}{r}76 . \\
2 \\
\end{array}$ & 65.6 & 55.1 \\
\hline SH1 & 463 & $\begin{array}{r}119 . \\
9 \\
\end{array}$ & $\begin{array}{r}54 . \\
6 \\
\end{array}$ & $\begin{array}{r}343 . \\
1 \\
\end{array}$ & 288.5 & 74.1 & 84.1 & 505.3 & 501.2 & 0.2 & $\begin{array}{r}0.2 \\
1 \\
\end{array}$ & $\begin{array}{r}99 . \\
2 \\
\end{array}$ & $\begin{array}{r}76 . \\
2 \\
\end{array}$ & 64.1 & 47.1 \\
\hline SH2 & 463 & $\begin{array}{r}104 . \\
2\end{array}$ & $\begin{array}{r}59 . \\
7\end{array}$ & $\begin{array}{r}358 . \\
8\end{array}$ & 299.1 & 77.5 & 83.4 & 505.3 & 501.2 & 0.2 & $\begin{array}{r}0.2 \\
3 \\
\end{array}$ & $\begin{array}{r}99 . \\
2\end{array}$ & $\begin{array}{r}69 . \\
6\end{array}$ & 58.0 & 44.6 \\
\hline
\end{tabular}

Even though the machine availabilities are relatively high (ranging from $68.8 \%$ to $100 \%$ ), the OEE per machine is astonishingly low in each case - and subsequently for the entire production line. This is a reflection of the potentials the factory possesses. From table III we can see the bottlenecks of each machine: the low OEE value for the Pre-breaker is due mainly to its low operation performance of barely 30.6\%; whereas machine availability improvement is a more pressing need for Crepper 2. Since the machines on the entire FC line are in series, a bottleneck machine is a real sore to the entire line.

To improve the effectiveness of each piece of equipment experiencing a loss, a project team made improvements to eliminate losses. A chronic machine (that with lowest OEE value) is focused upon and this machine is expected to show marked improvement under an intensive overhaul. This kind of team work has a dual benefit: it proves the effectiveness of OEE as a maintenance management analysis tool and gives the maintenance staff hands-on experience. It provides group leaders with the experience needed to improve other equipment in their individual work centres.

The pre-breaker was focused upon and its OEE value was further analyzed, in order to devise improvement strategies.

The line productivity in June was 0.66 tons of crumb rubber per hour and this rose to 1.08 tons per hour corresponding to the new OEE value of $49.93 \%$. Thus productivity is directly dependent on the OEE value of the production line. 


\section{CONCLUSION}

It is expected that the adoption of OEE calculations as a maintenance management analysis tool will save the company from making inappropriate purchases, and help management focus on improving the performance of machinery and plant equipment already owned. OEE index can be used to identify the greatest areas of improvement so that management can start with that which will provide the greatest returns on assets.

The OEE formula shows how improvements in quality, machine availability, working through breaks and more can affect the bottom line in a factory. The derived OEE percentage is easy to understand and displaying this single value where all factory personnel can view, makes for a great motivational technique. It could soon become common to glance at it, as the speedometer in a car. By giving the employees an easy way to see how they are faring in overall equipment utilization, production speed, and quality, they will strive for a higher value.

The data used for this work was manually collected. This is quite a tedious thing to do and the human factor introduces errors in the process, uses manpower hours and is cumbersome. This means OEE calculations cannot be done at sufficiently close intervals thereby erroneously portraying the tool as inefficient. The data collection could be automated for better efficiency, more reliable results, and economy.

As far as OEE per machine is concerned, it would be more informative to consider the rate of quality at the level of individual machines rather than the laboratory results that are carried out only at the end of the production process. In this way particular quality defects could be attributed to particular machines with precision. This will improve upon the precision of the OEE value obtained and the quality of the product enormously.

OEE index is an easy to use tool which can improve factory performance enormously and contribute to the industrialization drive in sub-SaharanAfrica.

\section{REFERENCE}

[1] Anonymous 2004A: Production Logbooks; CRF Tiko

[2] Anonymous 2004B: Quality Control Laboratory Results; CRF Tiko

[3] Evans et al; Applied Production and Operations Management, West Publishing Company, 1990 USA.

[4] Kersten T. Consultant JIPM/TPM Instructor (www.oeetoolkit.nl)

[5] www.vorne.com/www.oee.com

[6] www.oee.com

[7] S. Nakajima; Introduction to TPM: Total Productive Maintenance; Productivity Press, 1988 USA.

[8] The Vorne industries (www.vorne.com)

\section{LEGEND FOR OEE CALCULATION TABLES}

ACT: Actual Cycle Time i.e. Actual time taken to process one ton of crop

APT: Actual Processing Time (= OT - MS)

DTL: Downtime Losses

MS: Minor Stoppages

NOR: Net Operation Ratio $\left(=\frac{A F T}{O T} \times 100\right)$

OEE: Overall Equipment Effectiveness (OTR x OPR x QR)

OPR: Operation Performance Ratio (OSR x NOR)

OSR: Operation Speed Rate $\left(=\frac{T C T}{A C T} \times 100\right)$

OT: Operation Time (= PPT - DTL)

OTR: Operation Time Ratio $\left(=\frac{O T}{F F T} \times 100\right)$ i.e. Availability

Plus Losses: Total quantity of crop processed including off specification products

PPT: Planned Production Time

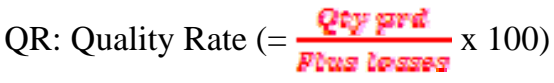

Qty prd: Plus Losses - defective products

TCT: Theoretical Cycle Time i.e. time to process one ton of crop

SC: Slab Cutter

PB: Pre-Breaker

CR: Crepper

SH: Shredder. 


\section{AUTHOR PROFILE}

G.N. Njeshu is an Industrial Maintenance/Production Engineer. He obtained his B.Tech (Hons) in 1997 from the Federal University of Technology Yola-Nigeria and his M.Eng in 2004 from ENSAI-University of Ngaoundere Cameroon. He has had seven years of experience as an industrial engineer and is presently a visiting Assistant Lecturer in the College of Technology (COT), University of Buea, and the College of Technology (COLTECH), University of Bamenda, all in Cameroon. He is equally on his Ph.D program in the department of Mechanical Engineering, MAUTECH Yola - Nigeria.

W.A. Acho holds two Masters, one in mechanical engineering (Lagos-Nigeria) and the other in mechatronics (Weingarten, Germany) awarded in 1992 and 2003 respectively. He lectured at the Obafemi Awolowo University Ile-Ife, Nigeria (1994-1997) and at ENSAI, the University of Ngaoundere, Cameroon (1998-2008). After close to nine years of practice in the industry, he is presently an Instructor and Interim Coordinator of the Mechanical Engineering program of the College of Technology (COT), University of Buea Cameroon.

N.D. Bup (Ph.D) is an Associate Professor of Applied Chemistry and Chemical Engineering at the University of Bamenda in Cameroon. He holds a B.Tech (Hons) in Industrial Chemistry from the Federal University of Technology Yola Nigeria and an M.Sc (Eng) and a Ph.D in Process Engineering from the University of Ngaoundere Cameroon. His research is on optimization of oil processing methods. 